Avaing Tera
Ling Tera, $6(1), 2019,30-40$

\title{
Interlanguage performed by students of English literature study program
}

\author{
Ayudya Whardani *, Margana Margana \\ Department of English Language Education, Program Pascasarjana, Universitas Negeri Yogyakarta. \\ Jalan Colombo No. 1, Karangmalang, Yogyakarta 55281, Indonesia. \\ * Coresponding Author. E-mail: devina.aisyah016@gmail.com \\ Received: 13 March 2018; Revision: 15 April 2019; Accepted: 19 June 2019
}

\begin{abstract}
The present study attempts to present the evidence of how learners of English as Second Language perform the target language by involving 20 participants from one of state universities in Yogyakarta. The participants are sitting in the first semester majoring English Literature. In investigating the target language performance this study used a writing assignment namely recount text in order to identify language development in relation to grammar acquisition comitted by the learners. Errors made by the learners tend to show interlanguage that the learners performance gains immediate status between native language and target language. The study found that the leaners explored 15 grammar aspects including past tense, modality, to + infinitive, gerund, make, passive voice, sentence elements, prepositions, articles, collocations, singular and plural nouns, pronouns, relative pronouns, question word order and native language transfer. The approximate cause of the errors are overgeneralization, learning strategy and native transfer. Moreover, overgeneralization becomes the most frequent in making errors that is by consistently using past tense in dealing with verbs. Thus, it is suggested that the teacher is necessary to sharpen the material spesifically based on actual evidence of learners' performance in order to accomodate what the learners need.
\end{abstract}

Keywords: interlanguage, grammar acquisition, writing assignment.

How to Cite: Whardani, A., \& Margana, M. (2019). Interlanguage performed by students of English literature study program. LingTera, 6(1), 30-40. doi:https://doi.org/10.21831/lt.v6i1.18867

This is an open access article under the CC-BY-SA license.

\section{INTRODUCTION}

Interlanguage is a phenomenon in the field of second language acquisition in which its presence will always exist as the acquirers are in language development. Interlanguage itself is not the only single terminology used to name the linguistic systems owned by L2 learners. The issue of interlanguage comes out after a long dissactifaction of the two previous theories namely Contrastive Analyis Hypothesis and Error Analysis. It is because there is no completely definite explanation about the influence of both mother tongue and target language towards target language performance. Since CA and EA are considered less sufficient for describing L2 errors, some other studies support this finding that neither MT nor TL are not fully responsible for learners' errors (Bailey, Madden, \& Krashen, 1974; S. D. Krashen, 1982; S. Krashen, 1989; Larsen-Freeman \& Long, 2014). Hence, Inter- language comes out with its own perspective as the continuum inverstigation of SLA.

The first one who introduces the term Interlanguage is (Selinker, 1972). He refers interlanguage as the knowledge systemacity of L2 independently of both MT and NL. Also, Richards (2015) describe interlanguage as a type of language system produced by those who are learning foreign language as the process of acquiring a new language. Nemser (1971) gives another name of interlanguage as approximate language. It is because interlanguage indicates the approximate language system learned by the L2 learners. It also means that interlanguage is nearly like native but its performance cannot be like native. Accordingly, (Brown \& Lee, 1994) labels interlanguage as the separateness of a L2 learners system. He explains that interlanguage gains an intermediate structural status that is between the MT and TL. Similarly. (Ellis, 2008, p. 33) states that a learner's language has a unique 


\section{LingTera,6 (1), 2019 - 31}

Ayudya Whardani, Margana Margana

system that it draws a recognition of the fact that L2 learners construct transitional competency that is different from their L1 as well as their L2. Again, the notion closely to interlanguage is stated by (Corder, 1982). He uses the term "transitional competence" to describe how learners of foreign language create their linguistic performance which do not match foreign language. In oder to illustrate how Interlanguage works, Selinker makes an illustration about Interlanguage cited from (Corder, 1982, p. 17).

From the Figure 1, Selinker is trying to generate that interlanguage is as the transitional processes between L1 and L2 that is observable and can be explored. Song (2012, p. 778) says that "this is better understood if it is regarded as a continuum between the native language and the target language". This continuum, the systemacity of learners, and some other differences occuring during the process of learning can be interesting things to notice as a part of learners' learning experience (McCarthy \& Carter, 2014).

In addition, two linguists Selinker (1972) and Tarone (2012) also present some characteristics of interlanguage. Selinker has three main characteristics including (1) permeability (2) dynamicity (3) systemacity. While (Tarone, 2012) propose four characteristics of inter-language such as (1) stability (2) systemacity (3) mutual intelligibility and (4) backsliding. Stability is devided into two, stability and instability.

Besides, the study of interlanguage can be related to teaching implication because its observation field deals with the learners. (Selinker, 1972; Tarone, 2012) adds that there is psycholinguistic process shaping interlanguage. Selinker (1972) lists several aspects including (1) native language transfer, (2) overgeneralization over target language rules, (3) transfer of training, (4) strategies of communication, and (5) learning strategies.

After reviewing interlanguage, the writer is interested in investigating interlanguage of L2 learners obtained from English literature pupils' writing performance in one of universities in Yogyakarta. Those learners are majoring English Literature sitting in the first year. The writer decides them as the participants of the study because they match the criteria of the interlanguage phenomenon that is their language performance are neither like L1 nor L2.

This phenomenon should be a concern because the learners belong to adult learners. Slabakova (2016, p. 142) based on Johnson and Newport's classical study (Johnson \& Newport,
1989) studies categorizes adult learners into those learners whose ages are 7 or 8 years old. It is also supported by Lenneberg that 6 years of age is the end of critical period for child language acquisition. Other literatures also propose that commonly adult learners belong to age of puberty (between 11 and 14 years old).

What can be inferred from this age cutting off is that it can be identified that these learners have acquired English at least more than 10 years. It is because According to Indonesian's curriculum namely $K 2013$, English is taught officially from junior high school to senior high school, but in some circumstances some of them have also acquired English in primary schools. It means that they have learned English for quite some times whether in natural context or formal context.

What makes it essential is that after this long time of learning their interlanguage may be stable. This phenomenon is called fossilization. Fossilization is about the stopping of learners' interlanguage. Ellis (2008) mentions some factors causing fossilization such as age, sex, social class and ethnic identity. In terms of age, those who start learning L2 after puberty will be less possible to have native like accent and less likely master grammatical comprehension than those who begin before (Hulin, 2013, p. 878).

In investigating learners' interlangauge, the writer chooses writing as the data source, for writing is essential for some ways like the need to do assignments (paper, essays, journals, etc.). Also, (Brown \& Lee, 1994, p. 491) says that it is important for L2 learners to comprehend writing skill. It is because, in school, writing is a way of life. If learners have no ability to pour their idea into writing, they will not pass the course. Further, writing involves language rules complexity, for in writing spesifically academic writing, the learners must deal with formal language arrangement causing them to explore more language styles and grammars. Therfore it will enable the researcher to explore their language products in which their writing performance can uncover several evidences which will be useful for teaching and learning implication.

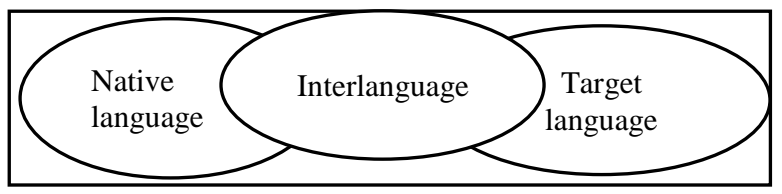

Figure 1. The notion of the IL (Corder, 1982) 


\section{LingTera,6 (1), 2019 - 32}

\section{Ayudya Whardani, Margana Margana}

By investigating the learners' interlanguage this study could be significant in some ways. The first is that it is useful for the teacher to know interlanguage made by the learners based on grammatical aspects seen from written form. Also, it is supported by (Al-Khresheh, 2015, p. 128; Pan, 2013) that the study of interlanguage can help the teacher in what L2 learners know at a particular point of time in and what they should be taught. Interlanguage study also may help the teacher to understand L2 learners' problem better, and by providing time to help the learners it is hoped that ther learners can achieve TL competence. Moreover, interlanguage brings in the acknowledment of the fact that errors are a part and parcel of the learning process, thus reducing the need for continuous supervision by the teacher (Ellis, 2008; Richards, 2015; Rustipa, 2011). Therefore, finding on learners' inter-language are advantageous to present siginificant changes in the teaching methogology

\section{METHOD}

This study took place in English Department in one of universities in Yogyakarta conducted in the odd semester in September 2016 untill January 2017. The source of the data was the drafts of learners' writing task performed by the first year of undergraduate students from English Department. The participants of the study were 20 learners out of 60 learners from two classes A and B chosen randomly. Table 1 shows the list of the participants of the study.

During the process of the study, the writer used steps adapted from the experts in order to make the writer easier to identify and classify errors. Gass \& Selinker (2013, p. 103) suggest the following steps: (1) Collecting data dealing with written data. (2) Identifying errors dealing with what kinds of errors (e.g., incorrect sequence of tenses, wrong verb form, singular verb form with plural subject) (3) Classifying errors. Is it an error of agreement? Is it an error in irregular verbs? (4) Quantifying errors dealing with couunting the frequencies of each kind of errors made by the learners. e.g. how many errors of agreement occur? How many irregular verb form errors occur? Etc.(5) Analyzing the cause of errors dealing with describing the errors by finding out the cause of errors. It could be found by doing deep analysis.
Table 1. List of the Participants Involved in the Study

\begin{tabular}{clll}
\hline Code & $\begin{array}{c}\text { Job } \\
\text { Description }\end{array}$ & Study Program & Gender \\
\hline IL1 & Student & English Literature & Female \\
IL2 & Student & English Literature & Male \\
IL3 & Student & English Literature & Female \\
IL4 & Student & English Literature & Female \\
IL5 & Student & English Literature & Female \\
IL6 & Student & English Literature & Female \\
IL7 & Student & English Literature & Male \\
IL8 & Student & English Literature & Female \\
IL8 & Student & English Literature & Male \\
IL10 & Student & English Literature & Female \\
IL11 & Student & English Literature & Female \\
IL12 & Student & English Literature & Female \\
IL13 & Student & English Literature & Female \\
IL14 & Student & English Literature & Female \\
IL15 & Student & English Literature & Female \\
IL16 & Student & English Literature & Female \\
IL17 & Student & English Literature & Male \\
IL18 & Student & English Literature & Female \\
IL19 & Student & English Literature & Male \\
IL20 & Student & English Literature & Male \\
\hline
\end{tabular}

In validating the data, this study fits the purpose of triangulation that is to validate the data in qualitative research. In triangulating the data, the writer uses investigator triangulation. The writer uses peer review involving a lecturer and a college to check the collected data. This process is done by cross checking the data in order to get the same idea of what the topic that the writer intends to carry. Since the topic of the study is about interlanguage, therefore the data collection is about investigating the systemacity of the language especially English. As the systemacity of the language of the study is in the level of syntax, therefore the data are related to grammars. The advantage of using triangulation is that the writer can feel more confident of the result of the study since during the process of crosschecking, among the writer, the investigator and the college have the same results.

\section{FINDINGS AND DISCUSSION}

To initiate the interpretation of the findings derived from recount text activity, the writer finds 15 aspects of error in relation to how the 20 learners explore grammars as presented in the following tables.

To start with, the learners as represented in (1) show that they mostly put verbs categorized as $B E$. The learners have misconception about the role of auxiliaries in a sentence, hence they put $\mathrm{BE}$ after the subject and then BE is followed by verb 2 to give marks that the sentences they make 
LingTera,6 (1), 2019 - 33

Ayudya Whardani, Margana Margana

happen in the past. This thing is caused probably by the misconception of BE application because this case does not happen only once. Examples of similar patterns occur frequently. It is proven that the learners are in the process in exploring grammars dealing with past events.The other problem related to determining verbs in past tense is that the learners do not know the right irregular verbs. It is seen from the sentences made in (2) that the learner does not know that the verb 2 of teach is taught. It is caused by a misunderstanding that the verbs of past tense are mostly ended with suffix $d / e d$, therefore they decide to just put the suffix $d / e d$ to sign that the verbs have changed into past form.

Table 2. Error in past tense

\begin{tabular}{lll}
\hline $\begin{array}{l}\text { Aspects } \\
\text { of Error }\end{array}$ & Data Code & Samples of the Data \\
\hline Past & IL1/WRT/RT & (1) They were look so \\
Tense & IL15/WRT/RT & $\begin{array}{l}\text { confuse so the } \\
\text { lecturer give his } \\
\text { explanation but I } \\
\text { think the lecturer } \\
\text { talked fastly } \\
\end{array}$ \\
& & (2) It teached me to care \\
& with each other. \\
\hline
\end{tabular}

Table 3. Error in modality

\begin{tabular}{ccc}
\hline $\begin{array}{c}\text { Aspects } \\
\text { of Error }\end{array}$ & Data Code & Samples of the Data \\
\hline Modality & $\begin{array}{l}\text { IL3/WRT/RT } \\
\text { IL2/WRT/RT }\end{array}$ & $\begin{array}{c}\text { (3) We were really } \\
\text { enjoyed it because } \\
\text { we could shared } \\
\text { our problem. }\end{array}$ \\
& & (4) ....., but we cannot \\
& & $\begin{array}{l}\text { to look view as it is } \\
\text { covered by a high } \\
\text { cliff. }\end{array}$ \\
& &
\end{tabular}

The problem with modality is seen in (3). It is when the learner tries to make positive statement. In this case the problem lies in the verb. It can be identified that these learners are misleading in applying modal auxiliaries for positive statement. The learner puts verb 2 after modal. Even though the meaning of the whole sentence can be caught, but this form is wrong syntactically. The right pattern is that the verb must be bare verb or infinitive. The second misconception is about making negative statement. Similar to what the learner has done in making positive sentences, in this part, the learner also makes error by putting the wrong verb after modal. The samples are shown in (4). The learner in prefers to put to + infinitive after negation of modals.
Table 4. Error in to + infinitive

\begin{tabular}{|c|c|c|}
\hline $\begin{array}{l}\text { Aspects } \\
\text { of Error }\end{array}$ & Data Code & Samples of the Data \\
\hline $\begin{array}{c}\text { To + } \\
\text { infinitive }\end{array}$ & $\begin{array}{l}\text { IL1/WRT/RT } \\
\text { IL9/WRT/RT }\end{array}$ & $\begin{array}{l}\text { (5) We had to paid } \\
\text { Rp 5000,- per } \\
\text { person. } \\
\text { (6) She gave us } \\
\text { chance to } \\
\text { imagination in } \\
\text { thirty minutes. }\end{array}$ \\
\hline
\end{tabular}

In (5), it can be seen that the learner has put inappropiate verb by choosing verb 2 to follow to. While in (6) the learner puts noun after to.As the rule suggests, the verb to follow after to must be bare verbs.

In (7) and (8) it can be seen that the learners use inappropiate verbs to follow verbs (start, kept, and enjoyed). Those verbs in the bracket gramatically must be followed by verb ing except start. The verb start can be followed by either verb ing or to + infinitive. However, in this case the learners prefer to choose past tense verb after enjoy/enjoyed and keep/kept. Therefore the correct verb phrases are (7) enjoyed singing and (8) kept forcing.

Table 5. Error in verbs + verb ing

\begin{tabular}{|c|c|c|}
\hline $\begin{array}{l}\text { Aspects } \\
\text { of Error }\end{array}$ & Data Code & $\begin{array}{c}\text { Samples of the } \\
\text { Data }\end{array}$ \\
\hline $\begin{array}{l}\text { Verbs } \\
\text { followed by } \\
\text { verb ing }\end{array}$ & $\begin{array}{l}\text { IL16/WRT/RT } \\
\text { IL19/WRT/RT }\end{array}$ & $\begin{array}{l}\text { (7) On the way, } \\
\text { we very } \\
\text { enjoyed sang } \\
\text { together. } \\
\text { (8)My friends } \\
\text { kept forced } \\
\text { me to speak } \\
\text { with them. }\end{array}$ \\
\hline
\end{tabular}

Table 6. Error in make

\begin{tabular}{|c|c|c|}
\hline $\begin{array}{l}\text { Aspects } \\
\text { of Error }\end{array}$ & Data Code & Samples of the Data \\
\hline Make & $\begin{array}{l}\text { IL10/WRT/RT } \\
\text { IL12/WRT/RT }\end{array}$ & $\begin{array}{l}\text { (9)That was my first } \\
\text { experience with } \\
\text { him and made me } \\
\text { more liked him. } \\
\text { (10) When I was } \\
\text { second grade in } \\
\text { Junior High School, } \\
\text { my school would } \\
\text { make a study tour } \\
\text { to Yogyakarta }\end{array}$ \\
\hline
\end{tabular}

Sample (9) indicates that the learner uses verb 2 (liked). Seen from the order of the structure of make, the learner has apllied the right order (make+ object + bare verb+ adj complement). They are only miss the form of the 
verbs. Therefore the verbs must be (9) like. Different case of make is found in (10). In this case the use of make is incorrect because make is uncommonly used in such English expression. Expression my school would make a study tour to Yogyakarta sounds unfamiliar because study tour is commonly hold, not made. This learner seems to exprerience false concept of hypothesiz-ed due to its misunderstanding in the use of make seen from this context.

Table 7. Error in passive voice

\begin{tabular}{|c|c|c|}
\hline $\begin{array}{l}\text { Aspects } \\
\text { of Error }\end{array}$ & Data Code & Samples of the Data \\
\hline & IL9/WRT/RT & (11) Theceremony \\
\hline Voice & IL19/WRT/RT & $\begin{array}{l}\text { was began at } \\
\text { (12.00 a.m. } \\
\text { Our fatigue, } \\
\text { hunger, and time } \\
\text { had paid here }\end{array}$ \\
\hline
\end{tabular}

Table 8. Error in sentence elements

\begin{tabular}{ccc}
\hline $\begin{array}{r}\text { Aspects } \\
\text { of Error }\end{array}$ & Data Code & Samples of the Data \\
\hline $\begin{array}{l}\text { Sentence } \\
\text { Element }\end{array}$ & IL12/WRT/RT (13) & $\begin{array}{l}\text { When I looked } \\
\text { out of the } \\
\text { window I } \\
\text { surpsised that } \\
\text { there was a } \\
\text { wonderful view. } \\
\end{array}$ \\
& (14) $\begin{array}{l}\text { Actually we not } \\
\text { came late yet } \\
\text { but we were } \\
\text { dissappointed we } \\
\text { couldnt see a } \\
\text { sunrise }\end{array}$ \\
\hline
\end{tabular}

As in (11) the problem lies in verb, but in this case the errorenous grammar is related to the use of past participle in passive voice. In (11) the learner puts past tense to follow to be auxiliary verb) resulting inappropiate structure of passive voice, for began is not the past participle but past tense. Therefore, the learner's sentence especially verb began must be changed into begun (past participle) The ceremony was begun at 08.00 a.m. Additionally, in (12), the learner again misses its verb. Similar to modal passive voice that after modal, auxiliary verb (be) is put. In perfective, after has/have/had, helping verb (been) must be put as well. The learner misses its helping verb (been) after perfective had.

In samples (13) and in (14), it can be identified that both sentences miss its verb auxiliaries including part of Be was and do. The first is in (13) that adjective suprised is not preceeded by was. It is because was is the past tense form of is and am, which are suitable to be used in recount text. It needs $B e$ (was), for after the subject, the words that follow after it belong to adjective and adverb of place. The next case relates to auxiliary do seen in (14). The learner uses (not) to show negation or negative form of come. Semantically, the meaning of the sentence can be catched. Nevertheless, in regards to grammar, clause in (14) should be revised into $I$ did not come late yet. It is because in making negative statement, the auuxilairy did is needed as a helping verb to connect subject and negative form of finite verb in past tense.

Table 9. Error in articles

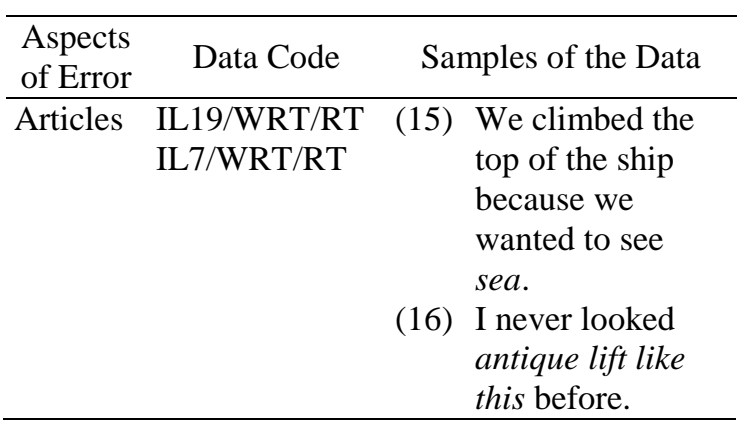

Samples (15) and (16) show the use of the two articles: definite article and indefinite article. In (15) problem with definite article the relates to the use of the to refer to larger situation. In this case the learner does not put the to preceed noun. Seen from the sentence that learner makes, it can be seen that a noun like sea needs to be preceeded by the. It is because sea needs the to presuppose that in our experience or fields of interest there is only one subject such as sun or sea. The next confusion in article is seen in (16) derived from noun phrases antique lift like this. Indefinite article $\mathrm{a} / \mathrm{an}$ is used to denote things in general in which in application it differs from its uses (a) nonreferring use and (b) the indefinite article and the numeral one. The sample is misleading in using article a/an belonging to nonreferring use of article. The position of noun phrase above is as an object or complement of a sentence. Besides its reference is also general. Therefore it is appropiate to add article a/an as the head of the noun phrase. becoming an antique lift like this.

Samples (17) and (18) deal with preposition. In (17) the problem is about preposition in to refer to a place. Based on English grammar, to share that we are in a country, a town, a building, and a room, the most appropiate preposition to use is in. Hence the prepositional phrase in (17) on Jakarta is correct if it is changed into in Jakarta. The second is about misconception over 


\section{Ayudya Whardani, Margana Margana}

the use of preposition on to declare time is seen in (18). The learner prefers using in to refer to days. On the contrary, to denote time particulary days and spesific dates, the most suitable preposition is $o n$.

Table 10. Error in preposition

\begin{tabular}{|c|c|c|}
\hline $\begin{array}{l}\text { Aspects } \\
\text { of Error }\end{array}$ & Data Code & $\begin{array}{c}\text { Samples of the } \\
\text { Data }\end{array}$ \\
\hline Prepositions & $\begin{array}{l}\text { IL7/WRT/RT } \\
\text { IL10/WRT/RT }\end{array}$ & 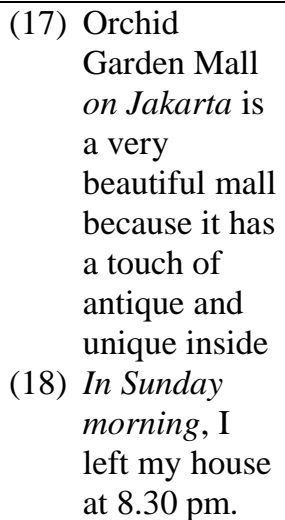 \\
\hline
\end{tabular}

Table 11. Error in collocation

\begin{tabular}{ccc}
\hline $\begin{array}{c}\text { Aspects } \\
\text { of Error }\end{array}$ & Data Code & \multicolumn{1}{c}{$\begin{array}{c}\text { Samples of the } \\
\text { Data }\end{array}$} \\
\hline Collocation & IL7/WRT/RT & (19) $\begin{array}{l}\text { Fanny was } \\
\text { interested } \\
\text { about the } \\
\text { flestival. }\end{array}$ \\
& & (20) $\begin{array}{l}\text { Similar with } \\
\text { the first event, } \\
\text { this event ran } \\
\text { smoothly. }\end{array}$ \\
& &
\end{tabular}

The misleading in collocation is shown in (19) and (20). The lists of samples in (19) and (20) are interested about and similar with. Based on English rule, the appropiate collocation for each is (19) interested in and (20) similar to. The word interested must be collocated with in because interested belongs to the strong collocation. Besides. word similar has its common collocation (to). In English, rarely do we find other word collocation for similar except (to). It is because similar is also categorized as strong collocation. The learner uses collocation similar with, for the learner may be influenced from the first language (bahasa). In bahasa the word similar has the same meaning to (sama halnya). It is common that in Bahasa sama halnya has a word pair dengan. The word dengan is equal to with in English. That is why the learner prefers choosing similar with rather than that of similar to.

In (21) and (22), the arrangement of question word phrase is incorrect. It is because when we intend to use question words in affirmative sentence either positive or negative, we must invert subject and verb. As in imperative sentence, full verb appears after helping verbs (do, did and to be) and subject. While in affirmative sentence, the position of subject and verb is inverted. Thus verb comes after subject just as in order of common sentence. The problem with this rule is seen in (21) I don't know where am I should be inverted into I don't know where I am. Similarly, in (22) the phrase how old is it should be inverted into how cold it is.

Table 12. Error in question word order

\begin{tabular}{|c|c|c|}
\hline $\begin{array}{l}\text { Aspects } \\
\text { of Error }\end{array}$ & Data Code & Samples of the Data \\
\hline $\begin{array}{l}\text { Question } \\
\text { word order }\end{array}$ & $\begin{array}{l}\text { IL5/WRT/RT } \\
\text { IL7/WRT/RT }\end{array}$ & $\begin{array}{l}\text { (21) I didn't know } \\
\text { where am I. } \\
\text { (22) Fanny only } \\
\text { walked around on } \\
\text { field of ice just } \\
\text { for knew how } \\
\text { cold is it. }\end{array}$ \\
\hline
\end{tabular}

Table 13. Error in Native Language Transfer

\begin{tabular}{lcc}
\hline $\begin{array}{c}\text { Aspects } \\
\text { of Error }\end{array}$ & Data Code & \multicolumn{1}{c}{$\begin{array}{c}\text { Samples of the } \\
\text { Data }\end{array}$} \\
\hline $\begin{array}{l}\text { Native } \\
\text { Language } \\
\text { transfer }\end{array}$ & IL14/WRT/RT & (23) First time I \\
entered boarding \\
school I was \\
delivered by my \\
big family, they \\
delivered me \\
happily while I felt \\
very sad, because I \\
thought that my \\
family abandoned \\
me \\
& & (24) After that, we \\
& next to Kawah \\
& Sikidang. \\
\hline
\end{tabular}

This section discusses about the influence of native language transfer as seen in (23), the learner writes First time I entered boarding school I was delivered by my big family, they delivered me happily while I felt very sad, because I thought that my family abandoned me. It is seen that the learner has chosen some uncommon words. The first uncommon word is enter. In this context, the learner chooses the word enter to preceed boarding school. What the learner means by this has similar expression like go to school. It is the situation where someone goes to a place namely school to get a formal study. The word enter itself is not common to pair with school. Enter has a meaning as get into. Its common expression is enter the room. This word choice might be influenced by first language 


\section{LingTera,6 (1), 2019 - 36}

\section{Ayudya Whardani, Margana Margana}

when community of the first language is going to school, they commonly say masuk sekolah. Hence, the word masuk is converted into English becoming enter. It is because in dictionary, the word masuk has similar meaning with enter. The next uncommon word used by the learner is deliver. In this context, what the learner means by deliver is similar meaning to accompany, come with and take somebody to.Similar to previous word, the learner uses the same strategy to express thing in the target language, that is by translating Bahasa into English. The learner intends to say mengantar, and in dictionary it shows deliver. However, mengantar does not fit the context in the learner's story, because deliver is commonly used to express an activity when something is sent or moved from one place to another place.

The other problem with word choice is also seen in (24). In this case, the learner consistently uses the word next to express a continuum but it is placed as a verb. The word next itself does not belong to verb, but adjective. In English, when a speaker wants to state a continuum, she/he can use the word continue. Translating, again is chosen by the learner in order to express Bahasa into English. This way is not always right because not all of words have the same meaning with its translation derived from the dictionary. In effect, it makes the expression sound unnatural.

Table 14. Error in singular and plural noun

\begin{tabular}{ccc}
\hline $\begin{array}{c}\text { Aspects } \\
\text { of Error }\end{array}$ & Data Code & $\begin{array}{c}\text { Samples of the } \\
\text { Data }\end{array}$ \\
\hline $\begin{array}{l}\text { Singular and } \\
\text { Plural Noun }\end{array}$ & $\begin{array}{l}\text { IL5/WRT/RT } \\
\text { IL7/WRT/RT }\end{array}$ & $\begin{array}{c}\text { (25) Wait } a \\
\text { minutes, I came } \\
\text { there now } \\
\text { (26) She looked } \\
\text { many unique } \\
\text { restaurant. }\end{array}$ \\
\hline
\end{tabular}

From the table of singular and plural form above, the learners are not aware of the singular rule that when the noun consist of only one variable, it means the noun does not need additional suffixes s/es. Noun phrase in (25) $a$ minutes is not well applied because the heads of the noun indicates that the noun to follow after it must be singular. Therefore a minutes must become a minute. The next is about plural noun. In this pasrt the learner is still confused in categorizing it into singular or plural. The learner follows quantifier with singular noun. It is not acceptable in English noun rule, for it must be followed by countable plural nouns. Noun phrase as in (26) many unique restaurant must be changed into, many unique restaurants it is because noun like restaurant belongs to contable noun, thus when it is preceeded by quantifiers like many, some, or few, those nouns should be added with suffixes s/es to sign that the nouns become plural.

Table 15. Error in pronoun

\begin{tabular}{ccc}
\hline $\begin{array}{c}\text { Aspects } \\
\text { of Error }\end{array}$ & Data Code & \multicolumn{1}{c}{ Samples of the Data } \\
\hline Pronoun & IL4/WRT/RT & (27) $\begin{array}{l}\text { So all of my } \\
\text { classmate has a } \\
\text { diary book and her } \\
\text { filled it with every } \\
\text { moment she had. } \\
\end{array}$ \\
& & (28) $\begin{array}{l}\text { Finally, the bus } \\
\text { driver asked our to } \\
\text { go there at } 12.00 \\
\text { a.m. }\end{array}$ \\
\hline
\end{tabular}

From samples as in (27), it can be seen that the learner has a peroblem in the use of pronoun in which function as a subject. In this case the learner uses pronoun (her) that is supposed to be an object. Whereas, in this sentence, what the learner means with her is to subtitute nouns in the previous clause. However, because this pronoun is put before verb to add a clause, hence the appropiate pronoun for (27) is they to refer to noun phrase all of my classmate. Additionally, in (28) shows how the learner intends to use pronoun as the object of the clause. Unfortunately, the learner has put inappropiate pronoun to subtitute noun which appears in the previous clause. As in (28) Finally, the bus driver asked our to go there at 12.00 a.m., what is shown in italic indicates that the learner chooses our to refer to the participants of the vacation because what the learner means is pronoun functioned as an object, therefore the pronoun must be changed into $u s$.

Table 16. Error in relative pronoun

\begin{tabular}{ccc}
\hline $\begin{array}{c}\text { Aspects } \\
\text { of Error }\end{array}$ & \multicolumn{1}{c}{ Data Code } & Samples of the Data \\
\hline Relative & IL11/WRT/RT & (29) When we were in \\
Pronoun & IL4/WRT/RT & $\begin{array}{l}\text { auditorium, we } \\
\text { listened rules who } \\
\end{array}$ \\
& we did and we \\
& couldn't did. \\
& (30) My friend whose a \\
& while ago brought \\
& my diary book \\
& was aid sorry to \\
& me. \\
\hline
\end{tabular}




\section{LingTera,6 (1), 2019 - 37}

\section{Ayudya Whardani, Margana Margana}

The first misuse of relative pronoun is about relative pronoun used to refer to subject (people) as seen in (29.). In this sentence, the relative pronoun chosen by the learner is inappropiate because what the learner intends to subtitute is noun (rules), hence the best relative pronoun to be put is which.

The next misuse of relative pronoun is found in (30). In this case, the learner uses whose to refer to the noun phrase (my friend). Because whose is used to refer to a posession, here, the learner follows whose with adverb and verb rather than noun. Hence, the purpose of whose to refer to my friend cannot be achieved. The most suitable relative pronoun to choose is who. It is because who is used to refer to people. Besides who is commonly followed by verb, for who has a function to act as a subject (people) of a sentence.

\section{The Cause of Interlanguage}

After interpreting the findings, it can be identified that learners interlanguage shows some characteristics such as dynamicity, systematicity, and stability. It can be seen in the Figure 2 .

The first is that learners language are dynamic. It can be seen that in this writing activity the learners explore 15 grammar items as listed in above table. Each grammar item has its own complexity resulting the difference precentage of each grammr item. The highest precentage of learners errors is derived from past tense $(85 \%)$,singular and plural $(75 \%)$, modality (70\%), missing sentence elements $(65 \%)$, words + gerund (60\%), preposition (50\%), and articles $(50 \%)$. They are categorized high because the precentage shows score value $50 \%$ and above $50 \%$. On the other hand, the lowest precentage are derived from grammar items such as relative pronoun $(10 \%)$, question word order $(15 \%)$, make $(25 \%)$ and collocation $(25 \%)$.

It is in line with what Song (2012, p. 778) says that interlanguage is constantly changing. It shows that learners' second language performance may develop as they explore new things of the target language. It is seen that learners have their tendency in making error with verbs but it does not occur when they deal with noun, and pronoun. Besides, according to (Selinker, 1972; Song, 2012, p. 779), interlanguage is systematic and predictable. Such predictable errors can be seen in the case when they deal with verbs. Because recount text commonly deals with event in the past, as a result the learners mostly focus on past tense verb as illustrated in the Figure 3.

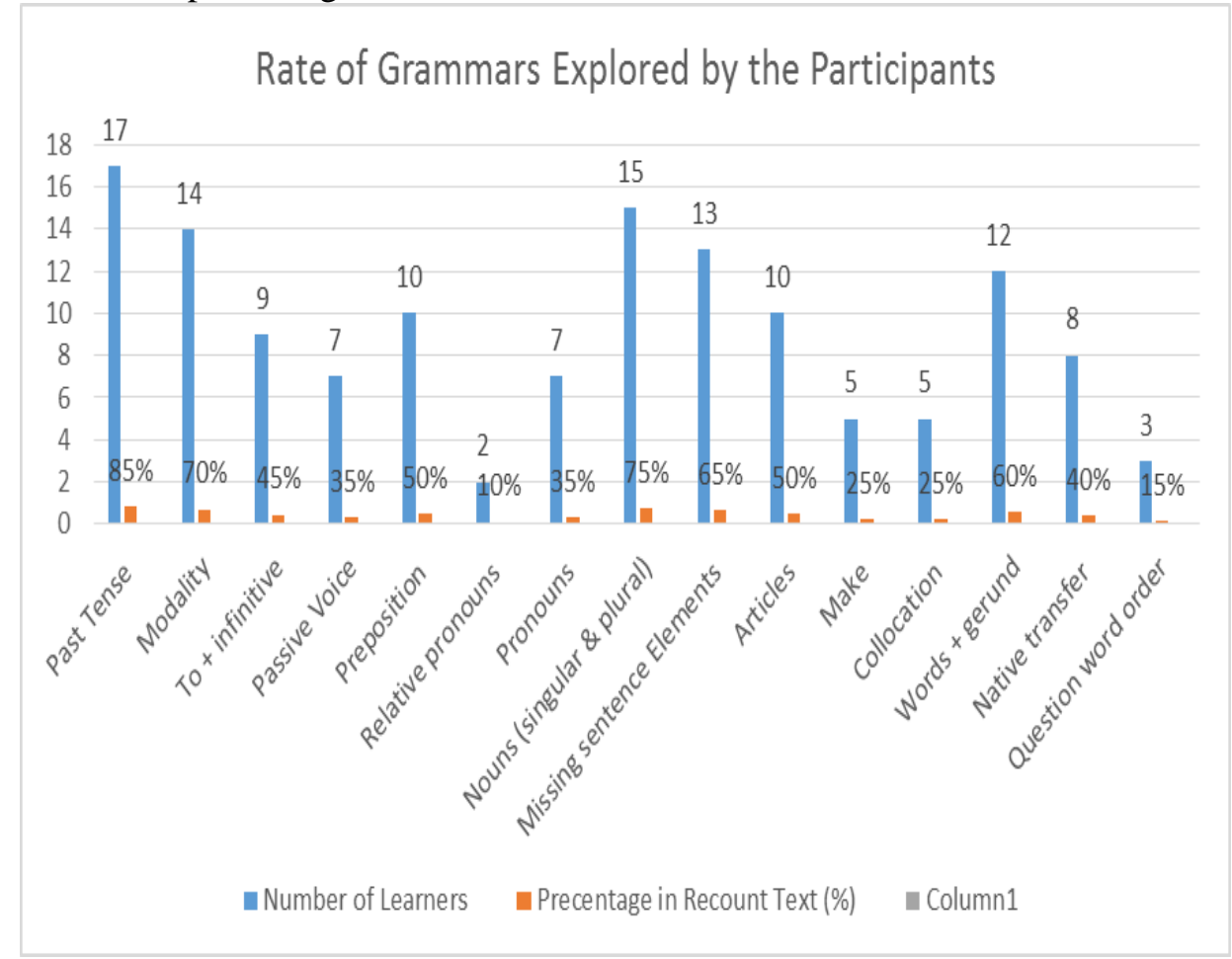

Figure 2. Rate of Grammars Comitted by the Participants 
LingTera,6 (1), 2019 - 38

Ayudya Whardani, Margana Margana

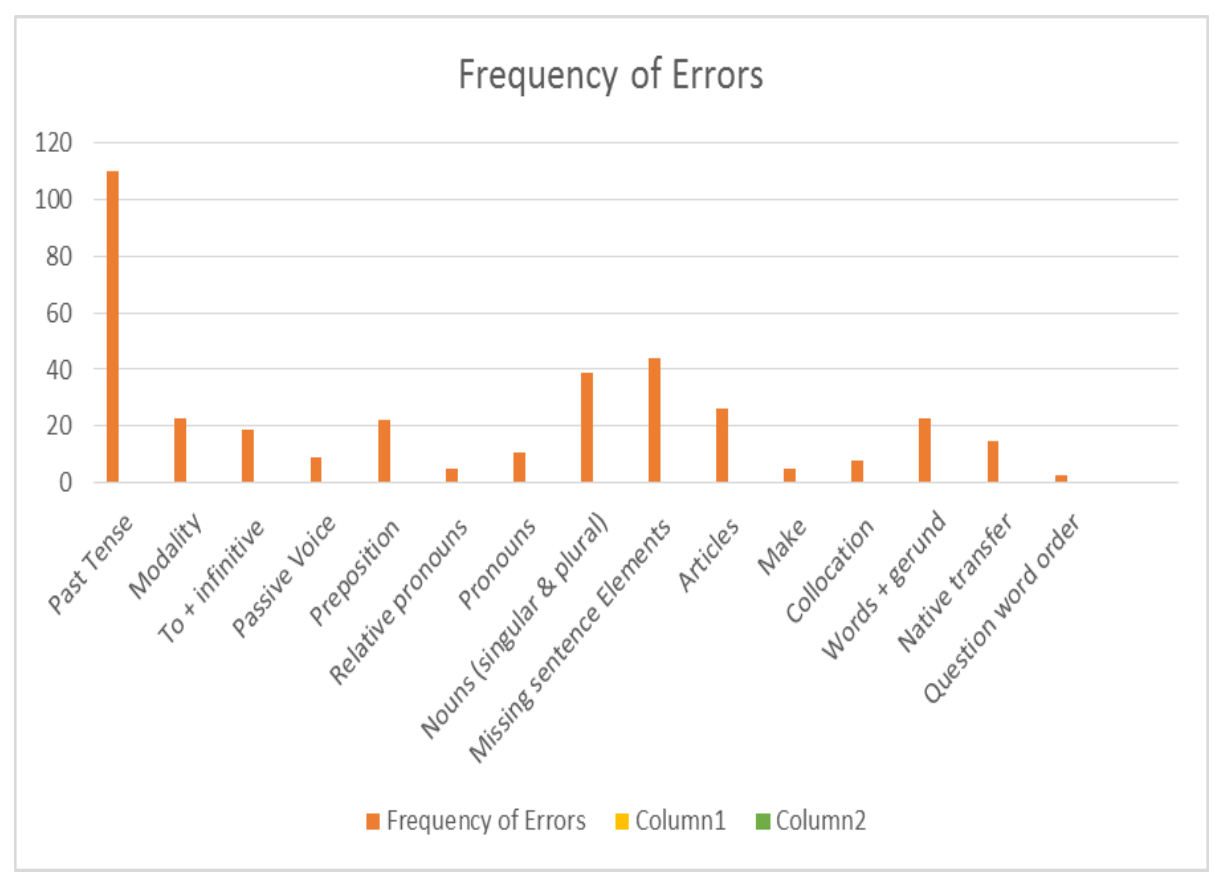

Figure 3. Frequency of Errors

The Figure 3 shows that some grammar aspects related to verbs are aspects which have high frequency of errors. The highest is placed by past tense (110 cases) and are followed by missing verbs in sentence elements (44 cases), words followed by gerund ( 23 cases). modality (23 cases), to +infinitive (19 cases), native transfer (15 cases) and passive voice ( 9 cases).The other aspects which are not related to verbs but they have high frequency of errors are noun phrase (singular and plural) (39 cases), articles (26 cases), preposition (22 cases), pronoun (11 cases), collocation (8 cases), relative pronoun (5 cases) and question word order ( 3 cases).

However, since English has a complex rule for verb, the learners make errors of grammars in which its verbs do not belong to past tense but gerund, bare verbs and infinitive. Such case is also called interlanguage stability proposed by Tarone (2012). He says that interlanguage can be stable because the learners make the same errors. The errors are not only made twice but even more.

In addition to discuss the pattern and the frequency of error, it is also important to find out the proximate cause of errors. (Selinker, 1972; Tarone, 2012) mentions four causes that shape learners interlanguage such as native language transfer, overgeneralization over target language, transfer of training, communication strategies and learning strategies.

In this study, the cause of interlanguage found mostly relates to overgeneralization over target language. Overgeneralization is found in the case where the learners deal with verbs such as past tensee, modality verb, to + infinitive, word + verb ing, and pattern of make. The learners seems to overgeneralize the use of verbs by always choosing past tense verbs to agree with modal, to do, make, preposition and verbs followed by gerund. The other proximate cause of errors is from learning strategies. This is the common thing to occur because it is not easy to encourage learners to learn. As what the behaviorists propose that language is habit formation, therefore this idea could be effective to improve language performance skill. Learning will enable the learners to find new information about the learnt new language. The last cause of interlanguage is from native transfer. It cannot be denied that when we learn new language we are still influenced by our first language. It is because learners ' first language are stored longer in the brain. Besides, new language's styles are sometimes share different rule from native. That is why in expressing something, it is common for the learners to express thing in target language but it is not familiar with the target language style.

\section{CONCLUSION}

As interlanguage becomes part of the learning process, in effect learners of second language cannot avoid these things. It is because learning is a process from not knowing to knowing making them experience failure or 
success. However, as the learners are guided to be more aware of deviant language performance in written or spoken form. It will enable the learners to achieve native like performance of the target language. Since errors are not considered as sins, this thing is advantageous for the learners to not worry about the errors, but it encourages them to learn more. Besides, the evidence of errors are useful as an actual evidence of how the learners generate target language. Therefore, this is what this is study all about.

In conclusion, it can be infererred that learners' interlanguage shows some characteristics such as dynamicity, systematicity, and stability. The fisrt is that learners language are dynamic that interlanguage is constantly changing. This idea is proven in this study that the learners are misleading in verbs acquisition but not with pronoun. It shows that learners' second language performance may develop as they explore new things of the target language. Besides, according to (Selinker, 1972; Song, 2012), interlanguage is systematic and predictable. Such predictable errors can be seen in the case when they deal with verbs. Because recount text commonly deals with event in the past, as a result the learners mostly focus on past tense verb. However, since English has a complex rule for verb, the learners make errors of grammars in which its verbs do not belong to past tense but gerund or infinitive. Such case is also called interlanguage stability proposed by Tarone (2012). He says that interlanguage can be stable because the learners make the same errors. The errors are not only made twice but even more.

Further, the learners' interlanguage is caused by three aspects involving overgeneralization over the target language, learning strategies, and native transfer. Among those three causes, overgeneralization over the target language becomes the cause which often appears especially when the learners deal with verbs. It is because the learners still stuck in the concept of past tense that the verbs used are verb 2 causing them to cosistently choose verb 2 to agree with some grammars like to +infinitive, modals, make, and words followed by verb ing.

\section{REFERENCES}

Al-Khresheh, M. H. (2015). A review study of interlanguage theory. International Journal of Applied Linguistics and English Literature, 4(3), 123-131. https://doi.org/10.7575/aiac.ijalel.v.4n.3p. 123
Bailey, N., Madden, C., \& Krashen, S. D. (1974). Is there a "natural sequence" in adult second language learning? Language Learning, 24(2), 235-243. https://doi.org/10.1111/j.14671770.1974.tb00505.x

Brown, H. D., \& Lee, H. (1994). Teaching by principles: An interactive approach to language pedagogy. Prentice Hall Regents Englewood Cliffs, NJ.

Corder, S. P. (1982). Error analysis and interlanguage. Oxford University Press.

Ellis, R. (2008). Understanding second language acquisition. Oxford university press.

Gass, S. M., \& Selinker, L. (2013). Second language acquisition: An introductory course. Routledge.

Hulin, R. (2013). Social perspective on fossilization of interlanguage.

International Journal of Asian Social Science, 3(4), 878-881. Retrieved from https://ideas.repec.org/a/asi/ijoass/2013p8 78-881.html

Johnson, J. S., \& Newport, E. L. (1989). Critical period effects in second language learning: The influence of maturational state on the acquisition of English as a second language. Cognitive Psychology, 21(1), 60-99. https://doi.org/10.1016/00100285(89)90003-0

Krashen, S. (1989). We acquire vocabulary and spelling by reading: Additional evidence for the input hypothesis. The Modern Language Journal, 73(4), 440-464. https://doi.org/10.1111/j.15404781.1989.tb05325.x

Krashen, S. D. (1982). Principles and practice in second language acquisition. Pergamon.

Larsen-Freeman, D., \& Long, M. H. (2014). An introduction to second language acquisition research. Routledge.

McCarthy, M., \& Carter, R. (2014). Language as discourse: Perspectives for language teaching. Routledge.

Nemser, W. (1971). Approximative systems of foreign language learners. IRAL International Review of Applied Linguistics in Language Teaching, 9(2), 115-124. https://doi.org/10.1515/iral.1971.9.2.115

Pan, Y. (2013). Applying second language acquisition research to English language 
LingTera,6 (1), 2019 - 40

Ayudya Whardani, Margana Margana

teaching in Taiwan. International Journal on Studies in English Language and Literature, 1(2), 1-12. Retrieved from https://www.arcjournals.org/pdfs/ijsell/v1 -i2/v1-i2-ijsell_1.pdf

Richards, J. C. (2015). Error analysis: Perspectives on second language acquisition. Routledge.

Rustipa, K. (2011). Contrastive analysis, error analysis, interlanguage and the implication to language teaching. Ragam Jurnal Pengembangan Humaniora, 11(1), 16-22.

Selinker, L. (1972). Interlanguage. IRAL International Review of Applied Linguistics in Language Teaching, 10(1-
4), 209-232. https://doi.org/10.1515/iral.1972.10.14.209

Slabakova, R. (2016). Second language acquisition. Oxford University Press.

Song, L. (2012). On the variability of interlanguage. Theory \& Practice in Language Studies, 2(4), 778-783. https://doi.org/10.4304/tpls.2.4.778-783

Tarone, E. (2012). Interlanguage. In The Encyclopedia of Applied Linguistics. Oxford, UK: Blackwell Publishing Ltd. https://doi.org/10.1002/9781405198431.w beal0561 